\title{
Hegemoni Kekuasaan dalam Novel Surat-Surat dari Dili Karya Maria Matildis Banda
}

\author{
Mey Dayanti $^{1^{*}}$, I G.A.A. Mas Triadnyani ${ }^{2}$ \\ ${ }^{[123]}$ Program Studi Sastra Indonesia, Fakultas Ilmu Budaya, Universitas Udayana \\ [1dayantimey@gmail.com], ${ }^{2}$ [mtriadnyani@gmail.com] \\ *Corresponding Author
}

\begin{abstract}
Entitled with "Hegemony of Power in The Novel Surat-Surat dari Dili Creation by Maria Matildis Banda". This research purpose are to know the structure and the hegemony that contained in the novel Surat-Surat dari Dili. There are three theories used in this research, which are structural theory by A. Teeuw, sociology of literature theory by Sapardi Djoko Damono, and the theory of hegemony by Raymond Williams. The method used in data collection are litereture study method which completed by technique note. Then continue using formal and informal methods to analyze the data. Furthermore, qualitative and quantitative method used as the presentation process of analysis data result, which are by interpreting and presenting data in the form of descriptions, tables, and diagrams. There are some revelation obtained based on the analysis in the novel Surat-Surat dari Dili. Firstly, in structural analysis that includes plot, characterization, and setting, they have relationships that related to each other. The relationship between the elements leads the reader to a theme, the hegemony of power. Secondly, the hegemony of the novel is divided into three processes, namely causes, implementation, and consequences. All three processes visible on events that occur, such as rape, put someone in jail, murder, and tragedy.
\end{abstract}

Keywords: novel, hegemony, power

\begin{abstract}
Abstrak
Penelitian ini berjudul "Hegemoni Kekuasaan dalam Novel Surat-Surat dari Dili Karya Maria Matildis Banda". Tujuan penelitian ini adalah untuk mengetahui struktur dan hegemoni kekuasaan yang terdapat dalam novel Surat-Surat dari Dili. Ada tiga teori yang digunakan dalam penelitian ini, yaitu teori struktural berdasarkan pendapat A.Teeuw, teori sosiologi sastra oleh Sapardi Djoko Damono, dan teori hegemoni dari Raymond Williams. Metode yang digunakan dalam pengumpulan data adalah metode studi pustaka dengan teknik catat. Kemudian dilanjutkan dengan menggunakan metode formal dan metode deskriptif analisis untuk penganalisisan data. Selanjutnya, dalam penyajian hasil analisis digunakan metode kualitatif dan kuantitatif, yaitu dengan cara menafsirkan dan menyajikan data dalam bentuk deskripsi, tabel, serta diagram. Berdasarkan analisis yang telah dilakukan terhadap novel Surat-Surat dari Dili ditemukan beberapa hal. Pertama, dalam analisis struktur yang meliputi unsur alur, penokohan, dan latar memiliki hubungan yang saling berkaitan antara satu dengan yang lain. Keterkaitan antarunsur tersebut menggiring pembaca menuju ke satu tema, yaitu hegemoni kekuasaan. Kedua, hegemoni kekuasaan yang terjadi dalam novel ini terbagi atas tiga proses, yaitu penyebab, pelaksanaan, dan akibat. Ketiga proses tersebut terlihat pada peristiwa yang terjadi, seperti pemerkosaan, menjebloskan seseorang ke penjara, pembunuhan, dan tragedi.
\end{abstract}

Kata kunci: novel, hegemoni, kekuasaan 


\section{Latar Belakang}

Perkembangan kajian sosiologi dalam dunia sastra semakin meningkat. Kajian sosiologi sastra banyak diminati karena karya sastra dianggap sebagai cerminan keadaan suatu masyarakat pada zamannya. Pemahaman tersebut membuat banyak mahasiswa sebagai peneliti menganggap bahwa kajian sosiologi sastra mudah dilakukan karena peneliti juga bagian dari masyarakat. Anggapan seperti itu menyebabkan pokok analisis dalam karya sastra menjadi tidak jelas. Terbukti dengan banyaknya analisis kajian sosiologi sastra yang serupa, pembedanya hanya terdapat pada objek penelitian. Padahal karya sastra satu dengan karya sastra yang lain memiliki ciri khas masing-masing yang tidak dapat disetarakan dalam satu kajian yang sama.

Permasalahan yang sering terjadi adalah peneliti kurang mengerucutkan pokok analisis, sementara sosiologi sastra merupakan ruang analisis yang sangat luas. Oleh karena itu, dalam penelitian ini pokok analisis berfokus pada satu masalah sosial, yaitu hegemoni. Salah satu karya sastra yang menjadikan hegemoni sebagai pokok permasalahan adalah novel Surat-Surat dari Dili (selanjutnya disebut SSD) karya Maria Matildis Banda. Novel SSD adalah novel yang lahir dari keprihatinan terhadap bencana kemanusiaan yang terjadi akibat tekanan sosial politik (Banda, 2005: 9).

\section{Pokok Permasalahan}

Berdasarkan latar belakang di atas, terdapat beberapa masalah yang dapat dianalisis, sebagai berikut.

a) Bagaimanakah struktur novel SSD karya Maria Matildis Banda?

b) Bagaimanakah hegemoni kekuasaan yang terdapat dalam novel SSD?

\section{Tujuan Penelitian}

Berdasarkan rumusan masalah di atas, terdapat tujuan yang ingin dicapai dalam penelitian ini, yaitu sebagai berikut.

a) Untuk mengetahui struktur novel SSD.

b) Untuk mengetahui hegemoni kekuasaan yang memicu terjadinya berbagai peristiwa dalam novel SSD.

\section{Metode Penelitian}

Sumber data penelitian ini adalah novel SSD karya Maria Matildis Banda yang terdiri atas 280 halaman. Metode yang digunakan dalam pengumpulan data adalah metode studi pustaka dengan teknik catat. Kemudian dilanjutkan dengan menggunakan metode formal dan metode deskriptif analisis untuk penganalisisan data. Selanjutnya, dalam penyajian hasil analisis digunakan metode kualitatif dan kuantitatif, yaitu dengan cara menafsirkan dan menyajikan data dalam bentuk deskripsi, tabel, serta diagram.

\section{Hasil dan Pembahasan}

Pembahasan dalam penelitian ini dilakukan dengan dua tahap analisis. Pertama, analisis struktur yang bertujuan untuk menjelaskan unsur karya sastra yang terdapat dalam novel $S S D$, kemudian dilanjutkan dengan menganalisis keterkaitan antarunsur. Hal ini berdasarkan pendapat Teeuw (2015:106) yang menyatakan bahwa analisis struktural bertujuan membongkar dan memaparkan secermat, seteliti, sedetail, dan sedalam mungkin keterjalinan dan keterkaitan semua unsur dan aspek karya sastra yang menghasilkan makna menyeluruh.

Kedua, dilanjutkan dengan analisis hegemoni kekuasaan yang bertujuan untuk membahas dan menjelaskan tentang hegemoni kekuasaan yang 
memicu berbagai peristiwa dalam novel SSD.

\subsection{Analisis Struktur}

Struktur karya sastra yang dianalisis, yaitu alur, penokohan, latar, dan tema.

\subsubsection{Alur}

Alur dalam novel SSD disajikan dalam sembilan bab yang diberi nama Surat Pertama hingga Surat Kesembilan. Dari penggambaran peristiwa-peristiwa yang telah dijelaskan pada setiap surat, terlihat bahwa tiap-tiap peristiwa itu saling berhubungan. Peristiwa yang satu dipersiapkan untuk peristiwa yang lain. Akan tetapi, tidak selalu peristiwa tersebut terjadi berdasarkan urutan kejadian. Misalnya, kembalinya Fernando ke perkebunan pada surat pertama bukanlah sebab dari peristiwa yang diungkapkan pada surat kedua, melainkan surat kedualah yang menjelaskan surat pertama.

Beberapa peristiwa yang terjadi memang berurutan sebagai sebab akibat, seperti yang terdapat pada surat kedua dengan surat ketiga. Sementara itu, ada juga peristiwa dalam beberapa surat yang akibat atau pengaruhnya diceritakan pada bagian akhir novel. Misalnya, hubungan antara surat pertama yang peristiwanya baru berdampak dan berlanjut pada surat kesembilan. Berikut rangkumannya dalam bentuk bagan. Adapun Bagan tahapan peristiwa di bawah ini dibuat berdasarkan pendapat Loban dan kawankawan (dalam Aminuddin, 2015:86).

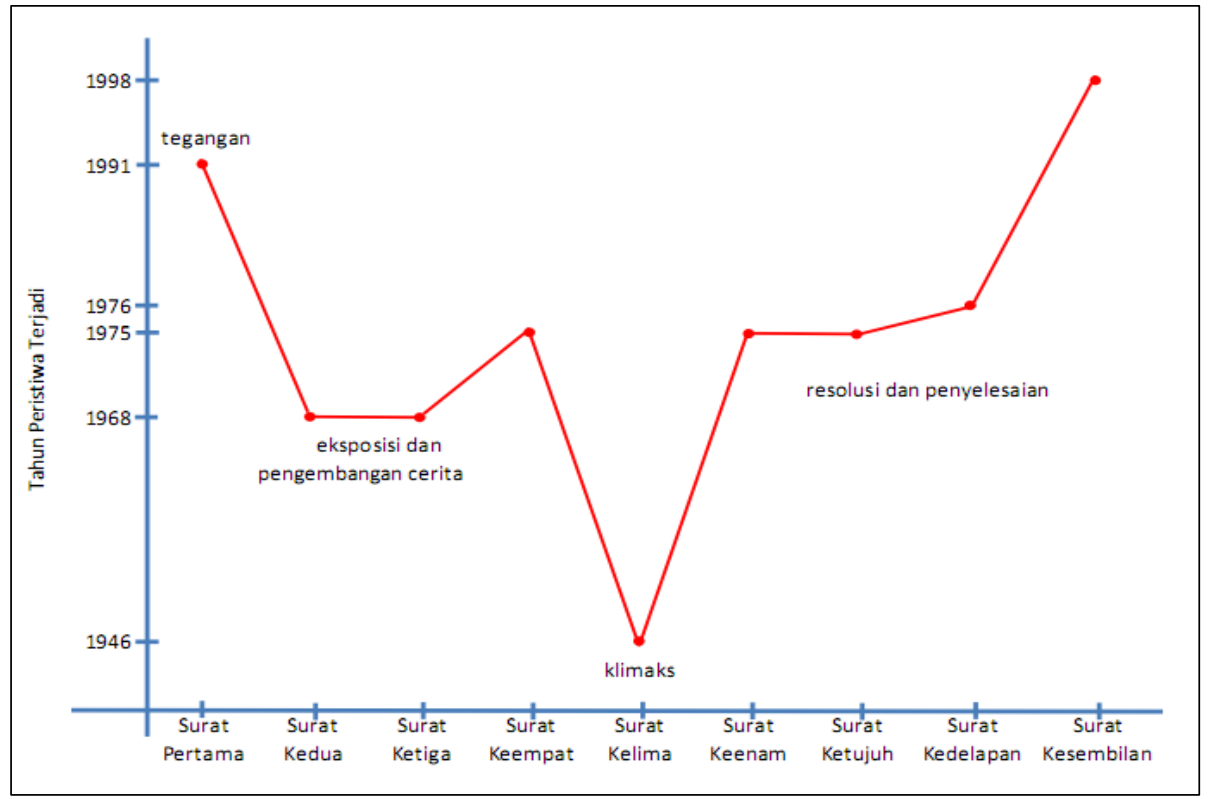

Gambar 5.1.1 Bagan Tahapan Peristiwa

\subsubsection{Penokohan}

Terdapat dua puluh sembilan tokoh yang berperan dalam novel SSD. Dua puluh sembilan tokoh tersebut terdiri atas lima belas tokoh utama dan empat belas tokoh pelengkap. Banyaknya tokoh dalam novel ini merupakan suatu kelebihan karena tidak ada tokoh yang tidak memiliki peran. Tokoh pelengkap yang kemunculannya paling sedikit pun memiliki peran penting dalam memberi dampak terhadap tokoh lain.

Dua puluh sembilan tokoh dalam novel $S S D$ melibatkan lebih dari dua keluarga besar yang saling berhubungan. Berikut ini bagan silsilah keluarga yang dibuat untuk mempermudah pemahaman terhadap hubungan antartokoh. 


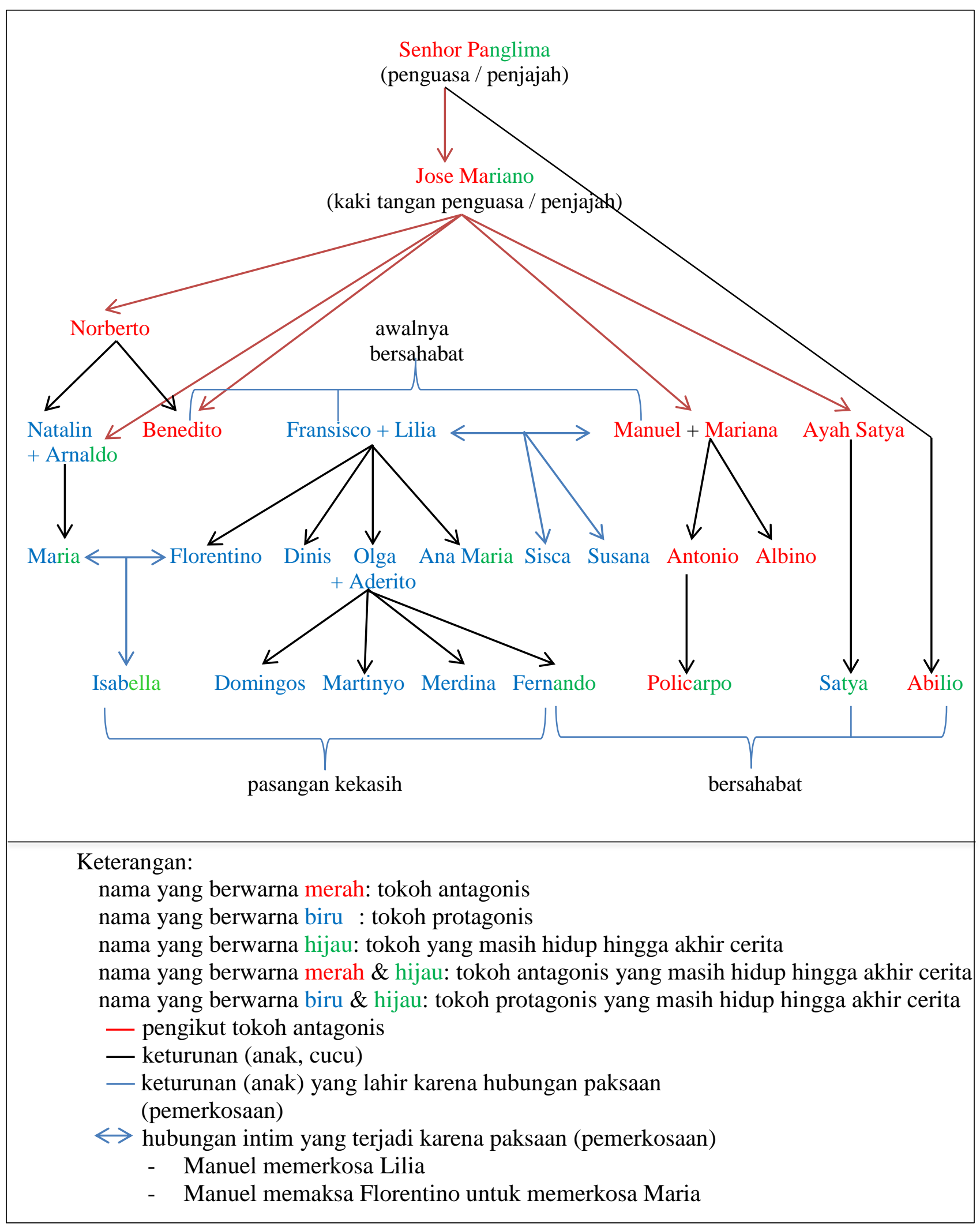

Gambar 5.1.2 Bagan Silsilah Hubungan Antartokoh 


\subsubsection{Latar}

Analisis latar dalam penelitian ini dilakukan dengan berpedoman pada pendapat Aminuddin (2015:67), yaitu dengan menganalisis latar berdasarkan fungsi fisikal dan fungsi psikologis. Latar dengan fungsi fisikal dan psikologis yang terdapat dalam novel SSD sudah terintegrasi dengan baik karena posisinya tidak dapat digantikan dengan yang lain. Maksudnya, dalam novel ini pengarang menyampaikan kehidupan masyarakat Timor Leste pada masa penjajahan yang sarat akan penjebakan, pembunuhan, pemerkosaan, dan perbuatan kesewenang-wenangan lainnya.

Dalam mengikuti cerita dan peristiwa-peristiwa yang terjadi pembaca diajak untuk memahami penderitaan masyarakat Timor Leste pada saat itu, seperti perang saudara, penghianatan, dan rasa saling curiga yang tidak mungkin diganti lokasinya dengan daerah lain. Dikatakan demikian karena belum tentu masyarakat di daerah lain merasakan penderitaan yang sama dengan masyarakat Timor Leste, sehingga jika unsur latar tersebut diganti maka lain juga cerita yang akan dihasilkan.

\subsubsection{Hubungan Antarunsur \\ 5.1.4.1 Alur dengan Penokohan}

Peristiwa-peristiwa dalam alur yang melibatkan tokoh akan membentuk konflik. Kemudian, konflik-konflik itu memengaruhi watak tokoh. Sebagai contoh, yaitu peristiwa pengeboman di Seminari Dare yang menewaskan Aderito, Martinyo, dan Domingos. Mengetahui suaminya meninggal dalam tragedi tersebut membuat Olga terdiam membisu hingga akhir hayatnya. Artinya, peristiwa tersebut memengaruhi bahkan membentuk perilaku tokoh (Olga).

\subsubsection{Penokohan dengan Latar}

$\begin{array}{ccc}\text { Latar } & \text { mengenai } & \text { kehidupan } \\ \text { masyarakat } & \text { Timor } & \text { Leste juga }\end{array}$

memengaruhi perilaku yang dilakukan tokoh. Menurut pendapat orang Timor, sebagai seorang laki-laki wajib hukumnya membalaskan dendam kerabat yang belum tersalurkan. Pemikiran tersebut yang memengaruhi Benedito dan Manuel untuk menghancurkan keluarga Fransisco karena dendam terhadap hukuman yang diterima Norberto. Bahkan ketika Manuel sudah meninggal, Policarpo sebagai cucu yang terjebak di antara dendam keluarganya pun harus ikut menyalurkan dendam tersebut dengan menghancurkan Fernando dan Isabella yang merupakan keturunan Fransisco.

\subsubsection{Latar dengan Alur}

Dalam novel SSD pembaca diperlihatkan pada berbagai peristiwa yang terjadi karena realisasi kebencian yang digunakan untuk menghancurkan orang yang dibenci. Peristiwa-peristiwa tersebut berupa pemerkosaan, penculikan, serta pembunuhan yang dialami oleh keluarga Fransisco. Penggunaan perkebunan kopi yang rindang dan gelap tentu sangat menunjang perbuatan jahat tersebut.

Banyak kejadian menyedihkan yang terjadi di perkebunan kopi dalam novel ini, mulai dari penjebakan Fransisco, pembunuhan Lilia, pemerkosaan Merdina, penembakan Sisca dan Susana, hingga penganiayaan yang berujung kematian Florentino dan Dinis. Semua kejadian tersebut tidak akan menciptakan suasana yang menegangkan dan menyedihkan jika latar tempatnya digantikan dengan lokasi lain. Hal ini berarti bahwa latar tidak hanya menunjukkan tempat dan waktu saja, tetapi dapat membentuk suatu peristiwa dan menjadi bagian dari peristiwa itu.

\subsubsection{Tema}

Setelah dilakukan penganalisisan terhadap struktur karya sastra beserta 
hubungannya, maka dapat disimpulkan bahwa tema novel SSD adalah hegemoni kekuasaan. Suatu dominasi kekuasaan yang menguntungkan satu pihak, yaitu pihak penguasa. Hegemoni menyebabkan orang yang memiliki kekuasaan berhak mendapatkan apapun yang diinginkan, terlepas dari benar atau salah perbuatan yang dilakukan. Hal ini menyebabkan pemilik kekuasaan bersikap sewenangwenang dan orang yang tidak memiliki kekuasaan harus menaati dan menerima kesewenang-wenangan tersebut.

\subsection{Analisis Hegemoni Kekuasaan}

Analisis hegemoni kekuasaan dalam penelitian ini dilakukan dengan dua tahapan. Pertama, analisis masalah sosiologi melalui peristiwa-peristiwa yang terjadi dengan menggunakan teori sosiologi sastra oleh Damono (2014:12). Kedua, analis hegemoni kekuasaan dengan mengamati proses hegemoni sesuai dengan teori yang dikemukakan oleh Raymond William (dalam Faruk, 2015:154).

Setelah dilakukan pembacaan berulang-ulang disertai dengan pengamatan, terdapat empat peristiwa yang menjadi peristiwa utama. Adapun keempat peristiwa yang dimaksud adalah pemerkosaan, memenjarakan seseorang ke penjara, pembunuhan, dan tragedi. Berdasarkan analisis terhadap keempat peristiwa tersebut, terlihat bahwa masalah sosiologi yang terklasifikasi dalam tujuh aspek (agama, moral, politik, hukum, ekonomi, sosial, dan budaya) merupakan bagian dari proses hegemoni kekuasaan yang terjadi. Berikut penjelasannya.

\subsubsection{Penyebab Hegemoni Kekuasaan}

Setelah melakukan pembahasan terhadap penyebab hegemoni kekuasaan melalui peristiwa yang terjadi, terlihat bahwa aspek moral dan aspek agama menjadi asal muasal berbagai peristiwa tersebut. Jika dihitung, jumlah keseluruhan aspek moral dan aspek agama yang terkandung dalam keempat peristiwa yang telah dianalisis berjumlah 26 aspek (23 aspek moral \& 3 aspek agama). Hal ini tentu bukanlah angka valid dari jumlah aspek moral dan aspek agama yang ada, tetapi setidaknya angka itu dapat menjadi gambaran mengenai seberapa besar pengaruh kedua aspek tersebut sebagai penyebab hegemoni kekuasaan. Adapun persentase antara aspek agama dan aspek moral dapat dilihat pada gambar berikut.

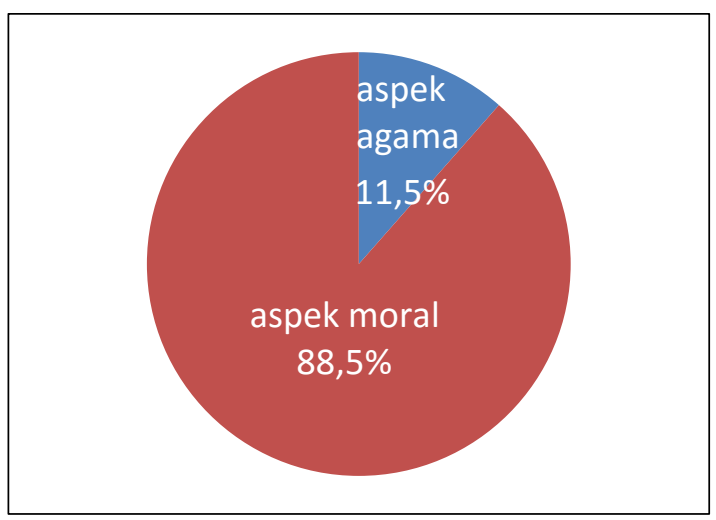

Gambar 5.2.1 Persentase Penyebab Hegemoni Kekuasaan

\subsubsection{Pelaksanaan Hegemoni Kekuasaan}

Setelah melakukan pembahasan terhadap pelaksanaan hegemoni kekuasaan melalui peristiwa yang terjadi, terlihat bahwa aspek hukum dan aspek politik menjadi cara pelaksanaan berbagai peristiwa tersebut. Jika dihitung, jumlah keseluruhan aspek hukum dan aspek politik yang terkandung dalam keempat peristiwa yang telah dianalisis berjumlah 27 aspek (17 aspek hukum \& 10 aspek politik). Hal ini tentu bukanlah angka valid dari jumlah aspek hukum dan aspek politik yang ada, tetapi setidaknya angka itu dapat menjadi gambaran mengenai seberapa besar pengaruh kedua aspek tersebut sebagai pelaksanaan 
hegemoni kekuasaan. Berikut adalah persentasenya.

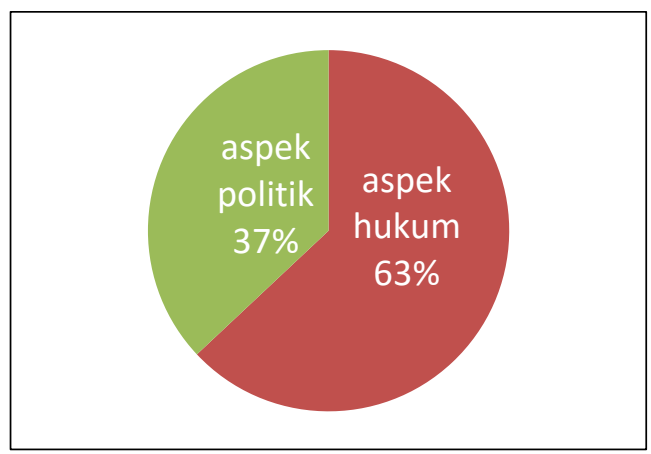

Gambar 5.2.2 Persentase Pelaksanaan Hegemoni Kekuasaan

\subsubsection{Akibat Hegemoni Kekuasaan}

Setelah melakukan pembahasan terhadap akibat hegemoni kekuasaan melalui peristiwa yang terjadi, terlihat bahwa aspek sosial, aspek budaya, dan aspek ekonomi menjadi akibat atas terjadinya berbagai peristiwa tersebut. Jika dihitung, jumlah keseluruhan aspek sosial, aspek budaya, dan aspek ekonomi yang terkandung dalam keempat peristiwa yang telah dianalisis berjumlah 33 aspek (18 aspek sosial, 23 aspek budaya, \& 3 aspek ekonomi). Hal ini tentu bukanlah angka valid dari jumlah aspek sosial, aspek budaya, dan aspek ekonomi yang ada, tetapi setidaknya angka itu dapat menjadi gambaran mengenai seberapa besar pengaruh ketiga aspek tersebut sebagai akibat hegemoni kekuasaan. Berikut adalah persentasenya.

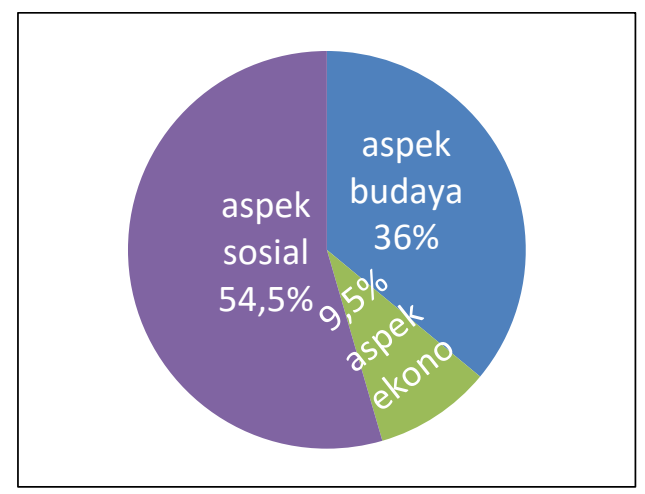

Gambar 5.2.3 Persentase Akibat Hegemoni Kekuasaan

\section{Simpulan}

Berdasarkan analisis struktur dan hegemoni kekuasaan pada novel $S S D$, dapat disimpulkan beberapa hal. Pertama, dalam analisis struktur yang meliputi unsur alur, penokohan, dan latar memiliki hubungan yang saling berkaitan antara satu dengan yang lain. Keterkaitan antarunsur tersebut menggiring pembaca menuju ke satu tema, yaitu hegemoni kekuasaan. Kedua, hegemoni kekuasaan yang terjadi dalam novel ini terbagi atas tiga proses, yaitu penyebab, pelaksanaan, dan akibat. Ketiga proses tersebut terlihat pada peristiwa yang terjadi, seperti pemerkosaan, menjebloskan seseorang ke penjara, pembunuhan, dan tragedi.

\section{Daftar Pustaka}

Aminuddin. 2015. Pengantar Apresiasi Karya Sastra. Bandung: Sinar Baru Algensindo.

Banda, Maria Matildis. 2005. Surat-Surat dari Dili. Flores: Nusa Indah.

Damono, Sapardi Djoko. 2014. Sosiologi Sastra (Pengantar Ringkas). Jakarta: Editum.

Faruk. 2015. Pengantar Sosiologi Sastra (dari Strukturalisme Genetik sampai Post-modernisme). Yogyakarta: Pustaka Pelajar Offset.

Teeuw, A. 2015. Sastra dan Ilmu Sastra. Bandung: Pustaka Jaya. 